\title{
NATION-BUILDING ORAZ NATION-PRESERVING W POLSCE W DOBIE TRANSFORMACJI I INTEGRACJI EUROPEJSKIEJ
}

\author{
Nation-building and Nation-preserving Activities in Poland \\ in the Age of Transformation and European Integration
}

The aim of the article is to show the centuries-old tradition of Polish elites working for nation-building and nation-preserving purposes. It dates back to at least the 18th century. The nation-preserving formula was developed in the 19th century, that is, during the partitions, when the Polish nation did not have its own statehood. In the first part of the article, I describe the specificity of Poles' historical experiences, primarily after the partitions that took place at the end of the 18 th century. I try to indicate three main approaches to nation-building (and nation-preserving) activities during this period. In the next part of the article, I try to show that this tradition lasted during the period of political transformation and European integration. While the nation-building approach, related to the reconstruction of sovereign statehood, democracy and a political nation, was dominant in the first case, the nation-preserving policy was observed more often, especially among the right-wing elites, after joining the EU, primarily due to the experiences of subsequent European crises.

Keywords: nation-building, nation-preserving, systemic transformation, European integration. 


\section{WPROWADZENIE DEFINICYJNE}

Pojęcie nation-building oznacza proces tworzenia narodu politycznego (lub wspólnoty politycznej). Chodzi o kreowanie tożsamości narodowej, a więc poczucia przynależności do określonego narodu politycznego przez dane społeczeństwo, w tym również w wyniku pokonywania różnic społecznych, a także integrację mniejszości w obrębie określonego narodu ${ }^{1}$. Proces nation-building opiera się więc na tworzeniu wspólnych wartości, idei, instytucji, odniesień historycznych itp. Tworzenie narodu politycznego ma na celu zwiększenie możliwości realizacji interesów tej wspólnoty politycznej w obrębie określonego państwa, a także w relacjach międzynarodowych, czego przejawem jest możliwość realizowania interesów narodowych wobec innych państw (i innych wspólnot politycznych).

Nation-building jest najczęściej definiowane jako polityka wykorzystująca struktury państwa w celu tworzenia narodu ${ }^{2}$. Jednak doświadczenia historyczne niejednokrotnie pokazuja, że podobne działania były podejmowane bez pomocy instytucjonalnej własnego państwa, np. w sytuacji utraty przez dany naród niepodległości lub w celu uzyskania suwerenności i własnego państwa. Dlatego w artykule wprowadzam pojęcie nation-preserving. Jest ono bardzo bliskie nation-building. $\mathrm{W}$ wielu sprawach oba terminy się pokrywają. Jednym $z$ aspektów nation-building jest tworzenie narodu w opozycji „do innego", najczęściej innych narodów ${ }^{3}$. W przypadku nation-preserving chodzi przede wszystkim o ochronę narodu przed zagrożeniami zewnętrznymi, które mogą zniszczyć tkankę narodowa, osłabić poczucie tożsamości narodowej albo osłabić podstawy funkcjonowania narodu politycznego. Tego typu zagrożenia moga wynikać m.in. ze słabnięcia państwa lub likwidacji niezależnego państwa będącego jednym $z$ najważniejszych instrumentów służących realizacji interesów określonej wspólnoty narodowej. Moga też wynikać $z$ działań ograniczających uczucia patriotyczne w danej grupie narodowej, likwidowania możli-

\footnotetext{
1 A. Wimmer, Nation Building: Why Some Countries Come Together While Others Fall Apart (Princeton Studies in Global and Comparative Sociology), Princeton University Press, Princeton 2018.

2 Nation Building in Comparative Contexts, eds. K.W. Deutsch, W.J. Folt, Atherton, New York 1966; H. Mylonas, Nation-building, w: Oxford Bibliographies in International Relations. ed. P. James, Oxford University Press, New York 2017.

3 A. Wendt, Social Theory of International Politics, Cambridge University Press, Cambridge 1999, s. 224-233; R.N. Lebow, A Cultural Theory of International Relations, Cambridge University Press, Cambridge 2008.
} 
wości posługiwania się językiem narodowym, jak również pielęgnowania tradycji, religii lub historii w łonie tej grupy.

Celem artykułu jest pokazanie wielowiekowej tradycji działania polskich elit $\mathrm{w}$ celu nation-building lub nation-preserving. Sięga ona przynajmniej XVIII wieku. Została rozwinięta w formule nation-preserving w wieku XIX, czyli w okresie rozbiorów, kiedy naród polski nie miał własnej państwowości. Później podobne doświadczenie spotkało Polaków także w wieku XX. Nic więc dziwnego, że te doświadczenia historyczne musiały mieć wpływ na polskie elity w momencie odzyskania niepodległości w roku 1989, zarówno w okresie transformacji ustrojowej, jak również później, po uzyskaniu członkostwa w Unii Europejskiej (UE).

W pierwszej części opisuję specyfikę doświadczeń historycznych Polaków, zwłaszcza po rozbiorach, które dokonały się pod koniec XVIII wieku. Staram się wskazać na trzy główne nurty podejścia do nation-building (oraz nation-preserving) w tym okresie. W kolejnej części artykułu staram się pokazać obecność tej tradycji w okresie transformacji ustrojowej oraz podczas integracji europejskiej. O ile w pierwszym przypadku dominowało podejście nation-building, zwiazane $z$ odbudowa suwerennej państwowości, demokracji i narodu politycznego, o tyle po wejściu do UE, a zwłaszcza pod wpływem doświadczeń kolejnych europejskich kryzysów - coraz bardziej widoczna była polityka nation-preserving, zwłaszcza wśród elit prawicowych. Metodyka mojej pracy opiera się na kwerendzie źródeł historycznych i opracowań naukowych w części historycznej, natomiast w odniesieniu do czasów najnowszych sięgam do programów partii politycznych i wypowiedzi polityków najważniejszych polskich partii politycznych.

\section{TRADYCJA HISTORYCZNA}

W przypadku Polaków i innych nacji Europy Środkowo-Wschodniej proces nation-building odbywał się przede wszystkim w wieku XIX i dokonywał się w bardzo specyficznych warunkach historycznych, mianowicie bez własnego państwa. W odniesieniu do narodu polskiego proces nation-building nawiązywał przede wszystkim do tradycji historycznej Pierwszej Rzeczpospolitej, która we wspólnym państwie gromadziła Polaków, Litwinów, Rusinów (później Ukraińców) i późniejszych Białorusinów, a także inne mniejszości (Żydów, Niemców). Niemniej ówczesna Rzeczpospolita tworzyła spójny naród polityczny 
- szlachtę, o wspólnej kulturze, języku i wartościach politycznych. Nation-building bazował więc na tradycji historycznej i kulturze, ale również religii chrześcijańskiej. Jednocześnie zasadniczym celem było odzyskanie własnego państwa - pełnej suwerenności. Omawiana polityka była też silnie zorientowana przeciwko mocarstwom zaborczym, a więc Rosji, Prusom (Niemcom) oraz Austro-Węgrom (choć wobec tego ostatniego podmiotu opór był zdecydowanie mniejszy, gdyż w obrębie tej monarchii naród polski cieszył się największą autonomia polityczna). W ten sposób ujawniła się specyfika omawianych procesów, która określam mianem nation-preserving.

Analizując historyczne fundamenty polityki nation-preserving, możemy wyróżnić trzy dominujące nurty. Pierwszy dotyczył odzyskania niepodległości, a więc oznaczał opór wobec wrogich państw zewnętrznych. Drugim nurtem historycznym procesów nation-preserving było pielęgnowanie narodowej kultury i tradycji, w tym również pamięci historycznej o Pierwszej Rzeczpospolitej. Wreszcie trzecim nurtem omawianych procesów było odwołanie do tradycji polskiego republikanizmu i demokracji szlacheckiej z okresu Pierwszej Rzeczpospolitej.

\section{TRADYCJA SUWERENNOŚCI}

Podstawowe znaczenie dla historycznej myśli politycznej miało odzyskanie suwerenności oraz obrona narodu przed zewnętrznymi wpływami politycznymi ${ }^{4}$. Dlatego ta tradycja zmierzała $z$ jednej strony w kierunku odrzucenia obcych struktur państwowych i administracyjnych, czyli służyła obronie narodu przed wpływami tych instytucji. $Z$ drugiej postulowała odbudowanie własnego państwa. Okres zaborów wytworzył w Polakach kompleks braku własnego państwa, z czym wiązały się różnorodne negatywne konsekwencje polityczne i gospodarcze dla narodu. Okazało się, że własne państwo jest najlepszym instrumentem nation-preserving oraz sposobem realizowania strategicznych interesów narodowych. Jednocześnie rozbiory wzbudziły niechęć do narzucania Polakom prawa i struktur administracyjnych, jak również przymusu edukacyjnego i wojskowego przez sąsiednie mocarstwa, które dominowały nad polskim narodem geopolitycznie.

Jeszcze w wieku XVIII Antoni Popławski domagał się od europejskich mocarstw poszanowania suwerenności nawet najmniejszych narodów politycznych. Uznawał, że każdy naród sam dla siebie powi-

\footnotetext{
4 A. Walicki, Polskie zmagania z wolnościa, Universitas, Kraków 2000, s. 225.
} 
nien być sędzia, a obce narody nie moga mu narzucać praw lub decyzji politycznych ${ }^{5}$. Wincenty Skrzetuski dostrzegał skłonność mocarstw określajacych samych siebie jako „cywilizowane” do podporzadkowywania i „wychowywania” innych państw traktowanych jako „dzikie”. Jednak choć można przekazywać dobre przykłady i w ten sposób zachęcać sąsiadów do doskonałości, jednak nie można tego dokonywać pod przymusem, majaccym w gruncie rzeczy prowadzić do politycznej dominacji jednych narodów nad drugimi ${ }^{6}$. Inny myśliciel polityczny tej epoki Hugo Kołłąaj uznawał, że każdy naród jest wolny i niepodległy, sam ma prawo ustanawiać dla siebie taką formę rządów, jaka mu się wydaje najlepsza, a żaden obcy naród nie ma prawa mieszać się w jego konstytucję. Naród pod zewnętrzną kuratelą traci niepodległość i przestaje zasługiwać na miano narodu ${ }^{7}$. Z kolei Stanisław Konarski dowodził, że największą niegodziwością dla Rzeczpospolitej jest, aby cudzoziemcy publicznie oskarżali obywateli i urzędy, a nawet samą Rzeczpospolitą o pogardę praw, chełpiąc się, że jakoby oni lepiej myślą o Rzeczpospolitej niż jej właśni obywatele ${ }^{8}$.

Niechęć do obcego państwa współgra w tradycji historycznej $z$ dażeniem do odbudowania silnej narodowej państwowości. Jeden $z$ myślicieli początku XIX wieku, Maurycy Mochnacki, uznawał za konieczne nie tylko odzyskanie niepodległości, ale zbudowanie silnej władzy państwowej, jak również nawoływał do wzmacniania ducha oporu wobec wszelkiej obcej władzy ${ }^{9}$.

Jeszcze przed rozbiorami - a więc pod koniec Pierwszej Rzeczpospolitej - cała plejada myślicieli politycznych nawoływała do wzmocnienia państwa, nawet jeśli odbywałoby się to kosztem demokracji szlacheckiej i wolności politycznych zagwarantowanych w ówczesnym ustroju. Tylko bowiem silna władza centralna - w tamtych realiach królewska - stwarzała szansę na uratowanie zagrożonej niepodległości. Przykładowo Stanisław Staszic wskazywał, że jeśli Polska chce utrzymać niepodległość musi zdecydować się na rządy absolutystyczne. Jego zdaniem, w całej Europie rzeczpospolitym (tj. demokratycznym wspólnotom politycznym) utrzymać się jest trudno, gdyż wszystko zmierza do samodzierżawia ${ }^{10}$. Kulminacja takiego sposobu

A. Popławski, Zbiór niektórych materii politycznych, Warszawa 1774.

W. Skrzetuski, Mowy o głowniejszych materyach politycznych, Warszawa 1773.

H. Kołłataj, O ustanowieniu i upadku Konstytucji 3 maja 1791 roku, Metz 1793.

S. Konarski, Epistolae familiares, sub tempus interregni, cz. 1-2, 1733; przekład polski: Listy poufne czasu bezkrólewia, tłum. W. Konopczyński, oprac. W. Konopczyński, Biblioteka Narodowa, seria I, nr 35, Kraków 1921.

9 A. Walicki, Polskie zmagania..., s. 239.

10 S. Staszic, Uwagi nad życiem Jana Zamoyskiego, Kraków (1787) 1926. 
myślenia były reformy wprowadzone przez Sejm Wielki (1788-1792) z Konstytucja 3 maja (1791) na czele. Zmierzały one do wzmocnienia władzy centralnej, a więc uprawnień króla, w tym w zakresie podatkowym i zwiększania możliwości wojskowych państwa. Naruszało to jednak wcześniejszy ustrój demokracji szlacheckiej, ograniczając uprawnienia narodu politycznego wobec władzy królewskiej.

Ten sposób myślenia o „sile państwa” był kontynuowany po odzyskaniu niepodległości w XX wieku przez Józefa Piłsudskiego i sanację. Siła państwa, rozumiana jako zdolność władzy do podejmowania decyzji mających bronić suwerenności, a tym samym zgodnych z założeniami koncepcji nation-preserving, miała większe znaczenie niż kultywowanie liberalnej demokracji i praw indywidualnych. W ten sposób w XX wieku rozważano możliwość wprowadzania elementów autorytarnych $\mathrm{w}$ trosce o niepodległość państwa i dobro narodu, co jednak swoimi korzeniami sięga do myśli i działalności politycznej w Pierwszej Rzeczpospolitej końca XVIII wieku.

Tradycja suwerenistyczna bardzo silnie akcentowała potrzebe samostanowienia narodu politycznego. Był on w Pierwszej Rzeczpospolitej rozumiany jako wspólnota całej szlachty (około 10 proc. populacji), mającej prawa polityczne w ramach ustroju określanego mianem demokracji szlacheckiej. Pomimo wieloetniczności tej wspólnoty politycznej uległa ona przez kolejne stulecia polonizacji. Tak więc kultura i język polski - obok tradycji republikańskiej - stały się głównym wyznacznikiem narodu politycznego. Obrona tego narodu przed zewnętrznymi wpływami nie tylko domagała się niepodległego państwa, ale również krytykowała mocarstwa tworzace imperia uniwersalne lub wielonarodowe ${ }^{11}$. Tego typu zarzuty stawia w pierwszej połowie XIX wieku Adam Jerzy Czartoryski państwom zaborczym. Uznaje on, że każdy naród posługujący się własnym językiem ma prawo do własnej państwowości. Jednocześnie Czartoryski był zaangażowany w kreowanie idei integracji europejskiej, a dokładnie wspólnoty ogólnoeuropejskiej, której najważniejszym zadaniem byłoby gwarantowanie praw narodów, nawet tych najmniejszych do własnej tożsamości i suwerenności. Nie była to więc idea powstania państwa federalnego lub wspólnoty politycznej wszystkich Europejczyków, ale raczej ładu ogólnoeuropejskiego mającego gwarantować prawa i istnienie poszczególnych narodów ${ }^{12}$. Według Czartoryskiego, idea europejskiej współ-

\footnotetext{
11 A. Nowak, O historii nie dla idiotów, Wydawnictwo Literackie, Kraków 2019, s. 438.

12 A.J. Czartoryski, Essai sur la diplomatie, Paris 1823, Rozważania o dyplomacji, Wydawnictwo Literackie, Kraków 2011.
} 
pracy narodów miała być kolejnym instrumentem nation-preserving, stawianym w opozycji do imperiów wielonarodowych i uniwersalnych, które zniewalaja słabsze lub mniejsze narody.

\section{TRADYCJA NARODOWEJ KULTURY}

Według Ernesta Gellnera współczesny nacjonalizm kształtował się w odmienny sposób w zachodniej i wschodniej części Europy. O ile na Zachodzie podstawa jego rozwoju były struktury państwowe, o tyle w Europie Środkowo-Wschodniej była nią kultura i język, co integrowało narody i zachęcało do starania się o niepodległość ${ }^{13}$. Jednym z przykładów tego zjawiska był polski nacjonalizm w okresie zaborów, który opierał się na kulturze, historii politycznej Pierwszej Rzeczpospolitej, języku i religii. Kultura była dla Polaków w XIX wieku obszarem, w którym najlepiej widoczne jest zjawisko nation-preserving. Polska tradycja, historia, obyczaje, język i katolicyzm stanowiły oparcie przed obcymi wpływami kulturowymi, w tym zorganizowana przez państwa zaborcze polityka rusyfikacji i germanizacji. Ponadto, jak to określił Andrzej Walicki - odwołanie do tradycji miało na celu urzeczywistnić ja w przyszłości, a więc umożliwić odbudowanie dawnej państwowości i suwerenności ${ }^{14}$.

Jean-Jacques Rousseau udzielił Polakom słynnej rady pod koniec XVIII wieku, że skoro nie moga zapobiec połknięciu przez potężnych sassiadów, to przynajmniej niech się postaraja, aby nie mogli oni ich strawić $^{15}$. W ten sposób myśliciel francuski stawiał staropolską kulturę jako fundament przetrwania narodu. $Z$ kolei romantyczna koncepcja narodu jawiła się jako „kreacja Boża”, a więc wybór dokonany przez opatrzność, który powoduje, że narody moga odgrywać swoje historyczne role. Według tego podejścia państwo było jedynie tworem ludzi, wtórnym wobec „Bożej kreacji”, co nadawało mu mniejsze znaczenie historiozoficzne ${ }^{16}$. Dlatego idea silnego narodu była niekiedy stawiana w opozycji do idei silnego państwa. O ile tradycja piłsudczykowska uwypuklała rolę państwa, o tyle dla Narodowej Demokracji (endecji) wiodące znaczenie miał naród, jego spójność i odporność na zewnętrzne, zwłaszcza kosmopolityczne lub liberalne wpływy.

${ }^{13}$ E. Gellner, Nations and nationalism, Blackwell Publishers, Oxford 1983, s. 97-101.

14 A. Walicki, Polskie zmagania..., s. 225.

15 J.J. Rousseau, Considérations sur le gouverment de la Pologne, 1772, Uwagi o rzadzie polskim, tłum. Maciej Staszewski, w: Umowa społeczna. Uwagi o rzadzie polskim. List o widowiskach, Państwowe Wydawnictwo Naukowe, Warszawa 1966.

16 A. Walicki, Polskie zmagania..., s. 248. 
Jednocześnie polska tradycja romantyczna przeciwstawiała naród uniwersalistycznej ideologii oświeceniowej, która odwoływała się do wolności, równości i braterstwa wszystkich ludzi. Także myśliciele okresu Sejmu Wielkiego podkreślali, że celem reform Pierwszej Rzeczpospolitej nie była ochrona praw indywidualnych - oświeceniowych praw człowieka - ale bytu całego narodu zagrożonego przez ościenne mocarstwa ${ }^{17}$. W przeciwieństwie do francuskiego oświecenia celem reform było wzmocnienie władzy królewskiej, a nie jej obalenie. W późniejszym okresie wielu polskich myślicieli nawoływało do ochrony narodowej tradycji i religii katolickiej, co odbiegało od oświeceniowego dążenia do wyzwolenia ludności z okowów tradycji i Kościoła.

Czas rozbiorów (1772-1918) był okresem intensywnych procesów nation-building. Jeszcze pod koniec wieku XVIII pojawiły się pomysły, aby włączyć do narodu politycznego inne - poza szlacheckim - stany, zwłaszcza mieszczaństwo i chłopstwo. Zarówno Staszic, jak i Kołłątaj widzieli potrzebę zbudowania nowoczesnego narodu - czyli włączenie do demokracji wszystkich stanów, jak również rozbudzanie $\mathrm{w}$ nich uczuć patriotycznych. Traktowali to jako warunek zachowania, a później odzyskania niepodległości.

Tak jak wspomniałem, pomimo wieloetniczności szlachta Pierwszej Rzeczpospolitej była spolonizowana i pod wieloma względami zintegrowana kulturowo. Także w późniejszych wiekach polska kultura przyciagała do siebie niemało „przychodźców” wywodzacych się ze środowisk żydowskich czy niemieckich, a wybierających polska tożsamość poprzez jej powiąanie $z$ ideałem walki o wolność ${ }^{18}$. Niemniej w XIX wieku pojawiły się idee oparcia narodu na etnicznych Polakach, jak również polonizowania innych grup etnicznych, ale też wykluczania $z$ narodu tych mniejszości, które w niewystarczającym stopniu się utożsamiały $z$ polskim językiem, kultura, religią i historią. Takie idee były zwłaszcza upowszechniane przez środowisko endecji, której liderem był Roman Dmowski. Na kanwie tych założeń kształtowała się wrogość części społeczeństwa wobec Ukraińców i Żydów. Ideolodzy endeccy - już po odzyskaniu niepodległości - oprócz systematycznej polonizacji tych mniejszości zalecali pozbawienie Żydów praw politycznych i tylko ich warunkowe przyznanie Ukraińcom, w zależności od ich lojalności wobec państwa polskiego ${ }^{19}$. Dodać można, że endecja negatywnie podchodziła do masonerii, która kojarzona była $z$ libera-

\footnotetext{
17 A. Nowak, O historii..., s. 429-430.

18 Ibidem, s. 452.

19 A. Walicki, Polskie zmagania..., s. 325.
} 
lizmem, kosmopolityzmem i wrogością wobec Kościoła katolickiego. Tymczasem dla środowiska endeckiego był on ostoją narodu.

Powiazanie polskiej tradycji narodowej z katolicyzmem było szczególnie silnie akcentowane właśnie w obozie Narodowej Demokracji. Niemniej ma ono wielowiekowa tradycję, sięgajaca kilkusetletnich zmagań $z$ muzułmanami na południowo-wschodnich rubieżach Pierwszej Rzeczpospolitej. W tych czasach powstała narracja o Polsce jako „przedmurzu chrześcijaństwa”, co oznaczało ochronę chrześcijańskiej Europy przed wrogimi krajami muzułmańskimi. Spektakularnym przykładem tej narracji była wiktoria wiedeńska króla Jana III Sobieskiego, kiedy to połączone siły Rzeczpospolitej i cesarstwa habsburskiego pokonały armię Imperium Osmańskiego pod wodza wezyra Kara Mustafy (1683). W XIX wieku polski romantyzm nadał patriotyzmowi wymiar mesjański. Polska została zmazana $z$ mapy politycznej Europy, a naród doznał rozlicznych cierpień niczym Chrystus. Ale te wszystkie doświadczenia miały odnowić najpierw ducha narodu, w tym również w wymiarze moralnym, a następnie przyczynić się do odnowy moralnej i religijnej całej Europy. W ten sposób romantycy stawiali Polaków w roli przywódców duchowych wszystkich Europejczyków, a nawet całej ludzkości ${ }^{20}$. Ten aspekt polskiej tradycji nation-preserving towarzyszy narodowi także później, czego przykładem sa współczesne odwołania polityków do konieczności obrony wartości chrześcijańskich w UE i odnowienia tej religii na Starym Kontynencie.

Warto również zauważyć, że powiązanie narodowej kultury z katolicyzmem było intensywnie wspierane przez Watykan. W XIX wieku papiestwo broniło w ten sposób własnych wpływów w Europie Środkowej i Wschodniej przed ekspansja z jednej strony protestantyzmu (wspieranego przez Prusy) oraz prawosławia (stymulowanego przez carska Rosję). W okresie PRL Watykan bronił Polaków przed intensywna laicyzacja promowana przez władze komunistyczne. Dodatkowym wsparciem dla katolicyzmu był autorytet moralny polskiego papieża - Jana Pawła II. Jego pierwsza wizyta do ojczyzny (1979) stała się zarzewiem dla wybuchu masowego poparcia społecznego dla związku zawodowego „Solidarność”, którego członkami w 1980 roku było $10 \mathrm{mln}$ Polaków (80 proc. wszystkich pracowników).

Warto też zwrócić uwagę, że powiąanie patriotyzmu z katolicyzmem i odnową moralna narodu czyniło wysiłki w kierunku nation-

20 Ibidem, s. 251. 
-preserving bezkompromisowymi, a nawet heroicznymi. Dążenie do odzyskania niepodległości, jak również procesy nation-preserving były traktowane jako absolutny priorytet, który musiał być ważniejszy od korzyści ekonomicznych, a nawet od zdrowia i życia Polaków. Najmniejszy kompromis był traktowany jako przejaw zdrady. Na tym zbudowano tradycję kolejnych powstań i zrywów narodowych przeciwko okupantom, poczynając od licznych powstań przeciwko zaborcom, przez powstanie warszawskie przeciwko Niemcom (z 1944 roku), a skończywszy na ruchu Solidarności $z$ lat osiemdziesiątych ubiegłego wieku. Te bunty społeczeństwa były za każdym razem kierowane przeciwko „obcym” - bo zależnym od zewnętrznej władzy politycznej - strukturom państwowym, administracyjnym i sądowniczym.

Należy jednak zauważyć, że obok tradycji heroicznej lub wręcz martyrologicznej, czyli gloryfikującej polskie cierpienia i kolejne klęski powstań przeciwko okupantom - w polskiej myśli patriotycznej pojawił się także nurt bardziej pragmatyczny i modernizacyjny. Jest on określany jako pozytywistyczny, gdyż w nawiązaniu do filozofii Auguste'a Comte'a stawiał racjonalne rozumowanie ponad emocjami. Wspomniany nurt zalecał rezygnację $z$ walki zbrojnej ze zbyt silnymi przeciwnikami, jakim były państwa zaborcze. Zamiast tego proponował skupienie się na modernizacji gospodarczej jako sposobie zbudowania "silnego narodu”, a także jego gruntownej edukacji, w tym $\mathrm{w}$ zakresie wychowania patriotycznego $\mathrm{w}$ niższych warstwach społeczeństwa (lub mniejszościach etnicznych). Zwolennikiem takiego podejścia do budowania narodu był m.in. Stanisław Staszic ${ }^{21}$. Choć ten nurt myślenia o nation-building był wprowadzany jeszcze w wieku XVIII, a następnie kontynuowany w kolejnych wiekach, to jednak nigdy nie zdobył dominujacej pozycji, zwłaszcza w stosunku do tradycji romantycznej.

\section{TRADYCJA REPUBLIKAŃSKA}

Ważnym elementem procesów nation-building była republikańska tradycja szlachecka, która bezpośrednio nawiązywała do spuścizny Republiki Rzymskiej. Była ona jednym $z$ fundamentów myśli politycznej Pierwszej Rzeczpospolitej i następnie była pielęgnowana w okresie rozbiorów jako ważny element narodowej tożsamości. Tradycja republikańska była często przywoływana w XIX wieku, kiedy porównywano Pierwszą Rzeczpospolita do ustrojów państw zaborczych, jak

\footnotetext{
21 S. Staszic, Przestrogi dla Polski, Warszawa 1790.
} 
również za każdym razem, kiedy Polacy odzyskiwali niepodległość i zastanawiali się nad własnym ładem politycznym. Nazwa państwa, czyli „Rzeczpospolita” - oznaczała w tradycji sarmackiej „rzecz wspólną wszystkim", czyli wspólnotę narodu politycznego. W Pierwszej Rzeczpospolitej takim narodem była szlachta, ale w okresie rozbiorów do narodu politycznego starano się włączyć resztę społeczeństwa. Rzeczpospolita była synonimem dobra wspólnego, a obywatele mieli obowiązek zaangażowania w sprawy publiczne. Naród był suwerenem, źródłem najważniejszych decyzji politycznych dotyczących losów państwa. Suwerenność szlachty miała ważny wymiar wewnętrzny, czego przejawem była obawa o dominacje władzy monarszej ${ }^{22}$. To „wola ludu”, czyli narodu politycznego, decydowała o najważniejszych kwestiach, w tym również o wyborze króla. Praktyka ta pojawiła się już w XIV wieku, ale została upowszechniona od drugiej połowy wieku XVI. Suweren - zinstytucjonalizowany w formie Sejmu i Senatu (parlamentu) - podejmował razem $z$ królem także inne ważne decyzje, w tym dotyczące powoływania osób na urzędy publiczne, w sprawie wojska, finansów państwa itp. W tych sprawach „wola ludu” nie mogła być ograniczana, na przykład przez arbitralne ustawy przyjmowane przez monarchę ani przez inne instytucje państwowe, na przykład władzę sądowniczą. W Pierwszej Rzeczpospolitej miała ona bardzo ograniczony charakter i nie mogła w żaden sposób interpretować decyzji politycznych parlamentu. Ponadto, szlachta nie miała skłonności do szanowania prawa, a więc cnoty, którą dzisiaj nazwalibyśmy respektowaniem rządów prawa ${ }^{23}$. Idea trójpodziału władzy, $\mathrm{w}$ tym niezależności sądownictwa od władzy parlamentu jest więc całkowicie sprzeczna $z$ tradycja polskiej demokracji. Jeśli historycy piszą o ustroju mieszanym Pierwszej Rzeczpospolitej, to dlatego, że $\mathrm{w}$ założeniach miał wprowadzić równowagę władzy między trzema instytucjami - monarcha, Senatem (skupiającym arystokrację) i Sejmem (przedstawicielami całego stanu szlacheckiego) ${ }^{24}$. Niemniej jest to podział de facto w łonie władzy ustawodawczej, co uwypuklało jej rolę ustrojowa, ale jednocześnie znacząco obniżało autorytet dwóch pozostałych Monteskiuszowych typów władzy, a więc wykonawczej i sądowniczej.

22 A. Nowak, $O$ historii..., s. 377.

23 D. Pietrzyk-Reeves, Ład Rzeczpospolitej. Polska myśl polityczna XVI wieku a klasyczna tradycja republikańska, Księgarnia Akademicka, Kraków 2012, s. 288.

24 S. Orzechowski, Mowa do szlachty polskiej przeciw prawom i ustawom Królestwa Polskiego, w: Wybór pism, oprac. J. Starnawski, Ossolineum, Wrocław-Warszawa-Kraków-Gdańsk 1972; D. Pietrzyk-Reeves, Ład Rzeczpospolitej..., s. 288. 
Zazdrość o prerogatywy Sejmu powodowała u szlachty niechęć do wzmacniania państwa, a zwłaszcza uprawnień władzy królewskiej. Tradycja republikańska Pierwszej Rzeczpospolitej jest więc ściśle związana $z$ obawa przed nadmierna centralizacja władzy (tendencja absolutystyczna - bądź mówiąc językiem współczesnym - autorytarna), co powodowało niechęć do silnego państwa. Została ona w tym aspekcie zmieniona dopiero pod wpływem traumy wynikajacej z rozbiorów.

Umiłowanie ojczyzny oznaczało w Pierwszej Rzeczpospolitej przede wszystkim troskę o dobro publiczne i wolności obywateli w sferze publicznej. Zdaniem Andrzeja Walickiego wyraźnie odróżniało to staropolska koncepcję wolności od oświeceniowych wolności indywidualnych, a tym samym od klasycznego zachodniego liberalizmu ${ }^{25}$. W centrum myśli politycznej Pierwszej Rzeczpospolitej było dobro narodu politycznego, a nie indywidualne prawa obywateli bądź człowieka. Szlachcic nie uważał się za osobę prywatną lecz publiczną. „Ludźmi prywatnymi byli plebejusze" ${ }^{26}$. Inną konsekwencją było przedkładanie dobra wspólnego ponad jednostkowe przywileje, w tym majątkowe. Własność królewska była własnościa państwa, kontrolowaną przez parlament. Podobnie własność prywatna była traktowana jako prawo warunkowe, które można było zawiesić lub wręcz odebrać w interesie dobra publicznego ${ }^{27}$. Nie znaczy to, że szlachta i inne stany nie miały praw indywidualnych, takich jak wolność słowa, wyznania, wolność majątkowa, podatkowa czy równość wobec prawa ${ }^{28}$, ale nie były one istota ustroju. Myśliciele republikańscy okresu Pierwszej Rzeczpospolitej dowodzili bowiem, że prawa jednostkowe moga być gwarantowane tylko w kraju wolnym, w którym obywatele moga decydować o sobie, tj. maja wpływ na władzę ${ }^{29}$.

Szlachta była ukierunkowana na aktywność polityczna, a jednocześnie pogardzała zajmowaniem się działalnością zarobkową. To pozostawiono innym grupom etnicznym, przede wszystkim Żydom i Niemcom. W ten sposób systematycznie niedoceniano rozwoju gospodarczego dla znaczenia geopolitycznego państwa, a także roli krajowego przemysłu dla potencjału wojskowego. Próba przełamania tej tradycji był dopiero ruch modernizacyjny (pozytywistyczny) czasu rozbiorów.

\footnotetext{
${ }^{25}$ A. Walicki, Polskie zmagania..., s. 226.

26 Ibidem, s. 231.

27 Ibidem, s. 234.

28 D. Pietrzyk-Reeves, Ład Rzeczpospolitej..., s. 258.

29 A. Grześkowiak-Krwawicz, Regina libertas. Wolność w polskiej myśli politycznej XVIII wieku, Słowo/Obraz Terytoria, Gdańsk 2006.
} 
Ważnym aspektem kultury politycznej Pierwszej Rzeczpospolitej była jednomyślność w sprawach istotnych. Polegała ona na niechęci do przegłosowywania w Sejmie przedstawicieli jednych województw przez inne województwa (posłowie byli wyłaniani przez miejscowe sejmiki). W ten sposób ustrój Pierwszej Rzeczpospolitej przypominał konfederację, w ramach której głosowanie większościowe uznawano za niedemokratyczne. Słynne „liberum veto” było później często krytykowane jako przyczyna słabości procesów decyzyjnych, co w rezultacie prowadziło do osłabienia kraju. Dla współczesnych i potomnych było przykładem anarchii życia publicznego, choć nie brak opinii, że było istota wolności republikańskich w Pierwszej Rzeczpospolitej.

Według historyków zwyczaj jednomyślności dotyczący najważniejszych decyzji przetrwał do czasów współczesnych, czego przejawem było postępowanie liderów związkowych w ruchu Solidarności ${ }^{30}$. Jego konsekwencja jest też niechęć do podejmowania decyzji większościowych $\mathrm{w}$ organizacjach międzynarodowych, m.in. w UE, co przez niektórych jest traktowane jako niedemokratyczne ${ }^{31}$.

\section{TRANSFORMACJA USTROJOWA - OKRES NATION-BUILDING}

Podejście nation-building zyskało na znaczeniu pod koniec XX wieku wraz z upadkiem Zwiazku Radzieckiego. Kluczowe znaczenie po roku 1989 miało odzyskanie niepodległości oraz transformacja ustrojowa i gospodarcza. Ważne było przywrócenie wolności politycznej, w tym tradycji republikańskiej, a więc możliwości demokratycznego decydowania o swoim losie przez naród polityczny. W ustroju politycznym ponownie główne miejsce zajał parlament (zgodnie $z$ tradycja Sejm i Senat). Ambicja elit politycznych było też ustanowienie nowej konstytucji. W jej inwokacji parlament wprost odwoływał się do „najlepszych tradycji Pierwszej Rzeczpospolitej”32. Jednocześnie jednym z najważniejszych świąt państwowych było celebrowanie rocznicy uchwalenia historycznej Konstytucji z 3 maja 1791 roku. Zwyczaj ten wprowadzono już po uzyskaniu niepodległości w ramach tzw. Drugiej Rzeczpospolitej (w 1919 roku), a następnie na początku Trzeciej Rzeczpospolitej (tj. w roku 1990).

\footnotetext{
30 A. Walicki, Polskie zmagania..., s. 242.

31 T.G. Grosse, Pokryzysowa Europa. Dylematy Unii Europejskiej, Polski Instytut Spraw Międzynarodowych, Warszawa 2018.

32 Konstytucja Rzeczpospolitej Polskiej z dnia 2 kwietnia 1997 roku, Dz. U. 1997, nr 78, poz. 483.
} 
Transformacja z państwa socjalistycznego (PRL) do Trzeciej Rzeczpospolitej oznaczała odzyskanie własnego państwa, a dokładnie przywrócenie go narodowi. Państwo nie było więc już dłużej instrumentem realizacji zewnętrznych interesów geopolitycznych (tj. Rosji i Zwiazku Radzieckiego, tak jak to było w czasach PRL [1945-1989]), niejednokrotnie wbrew interesom społeczeństwa polskiego, ale miało realizować interesy narodu politycznego.

Ważnym aspektem transformacji było przejście $z$ gospodarki socjalistycznej do kapitalizmu. Transformacja odbywała się w dużej mierze pod wpływem doradców ekonomicznych pochodzacych $z$ USA, w duchu neoliberalizmu i tzw. konsensusu waszyngtońskiego ${ }^{33}$. Reformy Leszka Balcerowicza i Jeffreya Sachsa zostały określone jako „terapia szokowa", gdyż radykalizm reform rynkowych wywołał recesję i był dotkliwy dla dużej części społeczeństwa. Jednym z kluczowych elementów tych reform była prywatyzacja przedsiębiorstw państwowych w dużej mierze inwestorom zagranicznym, głównie z USA i Europy Zachodniej. Wspomniane reformy były silnie popierane przez rządy państw zachodnich, jak również Komisję Europejska ${ }^{34}$. Tego typu podejście do gospodarki wyraźnie korespondowało $z$ tradycja Pierwszej Rzeczpospolitej, w ramach której działalność ekonomiczna pozostawiano innym nacjom. Naukowcy podkreślają, że wzorce rozwoju gospodarczego nie zmieniły się w Polsce na przestrzeni przynajmniej kilku stuleci, a utrzymujacy się w tym czasie dystans rozwojowy do Europy Zachodniej jest $\mathrm{w}$ dużym stopniu związany $z$ dominacja zewnętrznych inwestorów, nadmiernym poziomem konsumpcji, wreszcie imitacyjnym podejściem do metod rozwoju i technologii powstałych na Zachodzie ${ }^{35}$.

Polacy w ujęciu historycznym czuli się częścią Europy, nierzadko byli zafascynowani sukcesem gospodarczym mocarstw zachodnich, a nawet starali się bronić chrześcijańskich korzeni zachodniej części kontynentu przed agresją ze strony innowierców. Nic więc dziwnego, że dla wielu Polaków duże znaczenie miał powrót do wspólnoty demokratycznych państw Zachodu, czego wyrazem było ogromne poparcie

${ }^{33}$ B. Stanley, Poland, in: The Handbook of Political Change in Eastern Europe, eds. S. Berglund, J. Ekman, K. Deegan-Krause, T. Knutsen, Third Edition, Edward Elgar, Cheltenham-Northampton 2013, s. 169.

34 R.A. Epstein, Overcoming 'Economic Backwardness' in the European Union, JCMS 2014, t. 52, nr 1, s. 17-34; G. Medve-Bálint, The Role of the EU in Shaping FDI Flows to East Central Europe, JCMS 2014, t. 52, nr 1, s. 35-51.

35 A.C. Janos, East Central Europe in the Modern World: The Politics of the Borderlands from Pre- to Postcommunism, Stanford University Press, Stanford, CA 2000; R.A. Epstein, Overcoming... 
społeczne dla integracji z UE i NATO. Liberalne elity polityczne chciały zbliżyć się do Zachodu poprzez przyspieszona europeizację, czyli przyjmowanie zachodnich wartości, jak również pomoc w „cywilizowaniu", czyli otwieraniu na europejskie normy państw Europy Wschodniej $^{36}$. Ponadto, instytucjonalne zwiazki $z$ zachodnimi organizacjami miały wzmacniać proces nation-building. Zwłaszcza NATO, do którego Polska przystapiła już w roku 1999, miało bronić narodowej suwerenności, w założeniach przed zagrożeniem ze strony Rosji.

Nation-building był w okresie transformacji systemowej rozumiany przede wszystkim jako pielęgnowanie wolności, niepodległości i ochrona suwerenności. Jego celem była m.in. rewizja historii nauczanej w szkołach i przywrócenie wielu kart dziejów, które ukazywały dążenia Polaków do odzyskania pełnej niepodległości, począwszy od rozbiorów, powstań, przez walkę z Hitlerem i Stalinem, aż po okres PRL. Państwo ówczesne nie było suwerenne, bo bez pełnej wolności dla narodu politycznego i bez podporzadkowania działań tego państwa interesom narodu. Władze Trzeciej Rzeczpospolitej dokonały zmiany programów edukacyjnych przeznaczonych dla dzieci i młodzieży, aby znalazły się $\mathrm{w}$ nich tematy ważne $\mathrm{z}$ punktu widzenia patriotyzmu i wychowania obywatelskiego. Niezwykle istotnym instrumentem szerzenia wiedzy historycznej w społeczeństwie, jak również pogłębiania patriotyzmu było ustanowienie w 1999 roku Instytutu Pamięci Narodowej - Komisji Ścigania Zbrodni przeciwko Narodowi Polskiemu (IPN). Ten urząd państwowy, a jednocześnie jednostka naukowa, archiwalna, edukacyjna i prokuratorska, zajmuje się badaniem zbrodni niemieckich i sowieckich $z$ okresu II wojny światowej i PRL, karaniem winnych, jak również przekazywaniem do świadomości społeczeństwa wiedzy o nieznanych szerzej przestępstwach reżimu nazistowskiego i komunistycznego na polskim narodzie. Nation-building zmierzała do eksponowania narodowej historii zarówno wewnątrz kraju, w celu odbudowania patriotyzmu i tożsamości narodowej wśród Polaków, jak również na zewnątrz, w tym wobec Polonii (polskiej diaspory za granica) i wobec międzynarodowej opinii publicznej.

Ważnym elementem nation-building było uwypuklenie roli religii katolickiej dla tożsamości narodowej. Służyło temu m.in. wprowadzenie inwokacji do Boga w nowo uchwalonej Konstytucji (1997), wpro-

36 D. Woźniak, Through the East to the West: Poland's (re)entry into international society and the sway of memories of the Polish Golden Age, in: Memories of Empire and Entry into International Society: Views from the European Periphery, ed. F. Ejdus, Routledge, London- New York 2017, s. 84-99. 
wadzenie zajęć $z$ religii do wszystkich szkół publicznych na poziomie podstawowym i średnim, zagwarantowanie rozlicznych praw dla Kościoła katolickiego w Konkordacie między Stolica Apostolską i Rzecząpospolitą Polska (1993), jak również ustanowienie kilku świąt kościelnych jako świąt państwowych.

Podsumowujac, w okresie transformacji podstawowe znaczenie miały działania nation-building zwiąane $z$ przebudowa i wzmocnieniem państwa oraz pogłębieniem tożsamości narodowej i patriotyzmu wśród społeczeństwa. Taką politykę podejmowały przede wszystkim ugrupowania prawicowe, natomiast dla lewicy i partii liberalnych te kwestie miały mniejsze znaczenie lub w ogóle nie były postrzegane jako ważne. Ugrupowania postkomunistyczne oraz liberalne skupiały swój program na wprowadzaniu liberalnych reform rynkowych. Ponadto starały się upowszechniać liberalne podejście do kwestii moralnych, takich jak swoboda aborcji i zwiększanie praw dla mniejszości seksualnych. Były też nastawione antyklerykalnie do przywilejów Kościoła katolickiego w Trzeciej Rzeczpospolitej, jak również dystansowały się od patriotycznego podejścia prawicy, zwłaszcza w kwestiach polityki historycznej oraz kształtowania tożsamości narodowej wśród młodzieży. Głównym sloganem dla lewicy postkomunistycznej stało się hasło Aleksandra Kwaśniewskiego $z$ wyborów prezydenckich: „wybierzmy przyszłość”. Oznaczało ono budowanie wspólnej przyszłości dla narodu, zamiast rozpamiętywania historii, co było domena prawicy $^{37}$.

Jeśli więc uznamy, że polska lewica i liberałowie starali się budować naród w okresie transformacji, to odbywało się to wokół wartości liberalnych, zaczerpniętych głównie $z$ tradycji zachodniego oświecenia, jak również będąc zorientowanymi na integrację ze strukturami Zachodu. $Z$ kolei ugrupowania prawicowe prowadziły politykę nation-building w oparciu o historię zarówno tę dalszą sięgającej XVIII-XIX wieku, jak i najnowsza $z$ XX wieku. Ważne dla tych polityków było odniesienie do tradycji demokracji republikańskiej, wspomnienie długowiekowych zmagań o odzyskanie pełnej niezależności, jak również potrzeba budowania „silnego państwa” - w dużym stopniu zgodnie $z$ tradycja piłsudczykowska (sanacyjna). Patriotyzm i narodowe wartości miały zostać oparte na moralności religii katolickiej.

Istotnym aspektem nation-building stała się poprawa warunków życia społeczeństwa zmęczonego transformacją. Postulatem prawi-

37 A. Kwaśniewski, Wybierzmy przyszłość. Szkice programowe, Verum 1995. 
cowych polityków było dzielenie korzyści transformacji $z$ całym narodem, a nie tylko $z$ kręgiem wąskich elit powiąanych $z$ politykami liberalnymi, lewica postkomunistyczną (była nomenklatura) lub obcym kapitałem. Sukces wyborczy Prawa i Sprawiedliwości (PiS) $z$ roku 2005 został oparty na sprzeciwie wobec elit w interesie zwykłych Polaków ${ }^{38}$. Niemniej u podstaw tego podejścia była troska o naród doświadczony $\mathrm{w}$ okresie transformacji, jak również chęć redystrybucji korzyści ekonomicznych wynikających $z$ tej transformacji do niższych warstw społecznych. W ten sposób PiS łączył tradycję budowania „siły narodu” $z$ postulatami lewicowymi, opierajacymi się na rozlicznych programach redystrybucyjnych państwa. W jeszcze większym stopniu nawiazał do tej polityki, kiedy po raz drugi doszedł do władzy w roku 2019. Odwołał się mimochodem do tradycji modernizacji gospodarczej narodu, a więc tradycji pozytywistycznej, sięgającej XIX wieku. W czasie rząów tej partii coraz częściej podejmowano wysiłki na rzecz budowania narodowego przemysłu, w tym w sektorze bankowym, energetycznym i zbrojeniowym. Było to zgodne $z$ merkantylistycznymi pomysłami polskich myślicieli formułowanymi na przełomie XVIII i XIX wieku.

\section{CZŁONKOSTWO W UE - ROSNĄCA ROLA NATION-PRESERVING}

Po wejściu Polski do UE pojawiła się kwestia polityki państwa polskiego na forum europejskim. Zasadnicze znaczenie miało to, aby integracja wzmacniała polskie interesy, czego wyrazem było hasło „silna Polska w silnej Europie", aprobowane przez większość elit politycznych. Na poczatku członkostwa integracja europejska była postrzegana dość powszechnie jako szansa dla Polski w wymiarze geopolitycznym, gospodarczym i możliwość wzmocnienia państwa. Nawet później liberalna Platforma Obywatelska (PO) uznawała, że postępy integracji nie stanowią zagrożenia dla państwa i jego suwerenności, ale raczej szansę, pod warunkiem uczestnictwa w „głównym nurcie” polityki europejskiej. „Jeśli polskie sprawy będą omawiane przy głównym stole, będziemy umieli znajdować dla nich poparcie większości" 39 . Pomimo tego dostrzegano potrzebę pewnej ochrony autonomii państwa przed nadmierna tendencja centralizacyjna ze strony Brukseli. „Zgodnie

38 B. Stanley, Poland..., s. 184.

39 Przyszłość Polski - Wielki Wybór, 4 kwietnia 2019, https:/ / platforma.org/aktualnosci/przyszlosc-polski-wielki-wybor [dostęp: 27 marca 2019]. 
z zasada pomocniczości będziemy pilnować, aby decyzje w Unii zapadały na możliwie najniższym szczeblu - jak najbliżej ludzi, których dotycza". Ponadto, według prominentnego przedstawiciela tej partii Radosława Sikorskiego wiele kompetencji powinno zostać domena państw członkowskich, zwłaszcza w odniesieniu do „tożsamości narodowej, religii, stylu życia, moralności publicznej oraz stawek podatkowych"40.

Niemniej na początku XXI wieku Unia Europejska nie była kojarzona ze strukturalnym ograniczeniem roli państwa. Nie była więc organizacją, przed którą należałoby bronić polski naród. Sytuacja zaczęła się zmieniać wraz $z$ doświadczeniami płynącymi $z$ członkostwa w UE, które dowodziły, że niekoniecznie prowadzi ono do wzmocnienia państwa polskiego i polskiej suwerenności, a tym samym może osłabiać, zamiast wzmacniać naród polityczny i jego interesy. Duże znaczenie miały też kolejne kryzysy w Europie Zachodniej, które unaoczniały polskim elitom szereg zagrożeń, które dotykają Europę, słabość integracji europejskiej w odpowiedzi na te kryzysy, jak również słabość samych państw w przeciwdziałaniu tym zagrożeniom.

Przykładem zmiany nastawienia elit politycznych w Polsce do UE była kwestia przyjęcia wspólnej waluty. Początkowo pomysł ten budził szerokie poparcie elit i społeczeństwa. Pod wpływem doświadczenia kryzysu strefy euro politycy przyjęli zachowawcze stanowisko. Myślenie o wejściu do unii walutowej przez Polskę było możliwe dopiero wtedy, kiedy kryzys się zakończy, strefa euro się zreformuje, a dodatkowo polska gospodarka poprawi swoja konkurencyjnośćc1 . Wprawdzie później partie liberalne złagodziły swoje zastrzeżenia do wspólnej waluty, ale prawica nadal uznawała za konieczne obronę Polski przed członkostwem w unii walutowej. W ten sposób pod wpływem europejskich kryzysów kształtowało się podejście nation-preserving w polskiej polityce europejskiej, zwłaszcza w kręgach konserwatywnych.

Większość polskich partii politycznych od samego początku członkostwa w UE nie popierała pomysłów budowania federacji w Europie, obawiając się, że będzie to ograniczało polską suwerenność. Nawet, jeśli wspierano dalszy rozwój integracji w niektórych obszarach, to

40 Przemówienie ministra spraw zagranicznych Radosława Sikorskiego wygłoszone w Berlinie 28 listopada 2011, TVN24.pl, https://www.tvn24.pl/polska-a-przyszlosc-uniieuropejskiej, 192356,s.html [dostęp: 27 kwietnia 2018].

${ }^{41}$ Ch. Schweiger, Poland, Variable Geometry and the Enlarged European Union, „Europe-Asia Studies" 2014, t. 66, nr 3, s. 405-410. 
w taki sposób, aby nie budować superpaństwa, nie zwiększać centralizacji władzy w Brukseli lub biurokracji unijnej. Ponadto, kolejne polskie rządy udzielały poparcia dla rozwoju polityki zagranicznej i obronnej UE, lecz przy założeniu, że nie będzie to stanowić konkurencji lub zagrożenia dla NATO i relacji transatlantyckich. Najwyższym imperatywem pozostawało narodowe bezpieczeństwo. Stopniowo dostrzegano także ryzyko, że niektóre procesy integracyjne moga to bezpieczeństwo ograniczać, zamiast je zwiększać.

Jak się wydaje, w największym stopniu przywiazana do idei suwerenności i potrzeby budowania siły polskiego państwa było PiS. Dlatego wspomniane ugrupowanie najszybciej przyjęło wobec integracji europejskiej podejście nation-preserving. W programie tej partii podkreślono, że UE powinna pozostać wspólnotą suwerennych i równych narodów. Silne, sprawne i suwerenne państwo jest bowiem oparciem zarówno dla demokracji narodowej, jak również interesów narodowej wspólnoty politycznej. W swoich przemówieniach prezes PiS Jarosław Kaczyński wskazywał na potrzebę obrony państwa polskiego przed siłami zewnętrznymi i wewnątrzkrajowymi dążącymi do „landyzacji” kraju i wprowadzenia idei Europy regionów. W czasie jednej z kampanii wyborczej mówił: „Musimy wygrać, żeby bronić Polski przed w istocie anihilacja polskiego państwa"42.

Ochrona podmiotowości państwa polskiego oznaczała $z$ jednej strony sprzeciw wobec rosnącej władzy największych państw członkowskich w procesach integracyjnych. Dlatego podstawowa zasada premier Beaty Szydło w polityce europejskiej było: „równi $z$ równymi i wolni $z$ wolnymi" ${ }^{43}$. PiS chciał więc równości państw w UE i eliminowania podwójnych standardów w podejściu do większych i mniejszych krajów w tej organizacji ${ }^{44}$. Zamierzał także zerwać $z$ polityką klientelizmu wobec najsilniejszych krajów, co zarzucał swoim poprzednikom. Według programu tej partii, w polityce europejskiej należy kierować sie przede wszystkim własnymi interesami narodowymi, a nie oczekiwaniami najbardziej wpływowych partnerów ${ }^{45}$. Kaczyński podkreślał, że nie chce Europy, w której Polska będzie wykonywała czyjeś

${ }^{42}$ J. Kaczyński, Mamy do czynienia z coraz jawniejszym przejawem hejtu, który nie ma nic wspólnego z faktami, wPolityce.pl, 15 czerwca 2019, https://wpolityce.pl/polityka/ 451099-kaczynski-mamy-do-czynienia-z-coraz-jawniejszym-hejtem [dostęp: 29 lipca 2019].

43 Przemówienie Premier Beaty Szydło na XV Forum Polityki Zagranicznej, 9 listopada 2017, http://www.minsk.msz.gov.pl/pl/aktualnosci/xv_forum_polityki_zagranicznej [dostęp: 27 kwietnia 2018].

44 Program PiS 2014, http://pis.org.pl/dokumenty, s. 158 [dostęp: 27 kwietnia 2018]; Deklaracja Europejska PiS, pkt. 9, http://pis.org.pl/dokumenty [dostęp: 27 kwietnia 2019].

45 Program PiS 2014, s. 154. 
polecenia lub będzie czyimś klientem, ale takiej, w której będzie mogła realizować - tak jak inne kraje - swoje narodowe interesy ${ }^{46}$.

$Z$ drugiej strony politycy PiS byli przeciwni dalszej centralizacji uprawnień w UE, a tym samym chcieli spowolnić postępy integracji ${ }^{47}$. Uznawali, że kompetencje instytucji unijnych nie powinny być poszerzane bez zmiany traktatów. „Komisja Europejska nie jest ani superrządem, a PE nie jest superparlamentem”, a wszelkie „kompetencje nieprzyznane Unii $\mathrm{w}$ traktatach powinny należeć do państw członkowskich"48. Jednocześnie PiS z niepokojem obserwował zwiększanie dyscyplinarnego nadzoru nad państwami członkowskimi ze strony instytucji unijnych i wymuszanie stosowania przez nie prawa unijnego $^{49}$. Ponadto, polska prawica krytycznie zapatrywała się na pomysły wprowadzenia nowych europejskich podatków lub harmonizacji podatkowej na rynku wewnętrznym, uznając, że polityka fiskalna jest traktatowa kompetencja państw członkowskich, zwłaszcza demokratycznych parlamentów narodowych. Tak samo podchodziła do polityki imigracyjnej, jako przynależnej suwerennym państwom.

Kryzys migracyjny w UE walnie przyczynił się do nastawienia nation-preserving wśród polskich elit politycznych. Rząd PiS nie zgadzał się na przymusowe kwoty relokacji uchodźców w UE. Był przeciwny centralizacji zarządzania polityką migracyjną w Brukseli. Proponował umocnienie granic zewnętrznych UE oraz zintensyfikowanie działań $\mathrm{w}$ ramach polityki humanitarnej i rozwojowej poza jej granicami ${ }^{50}$. W ten sposób zamierzał chronić narodową kulturę i tożsamość, traktując proponowana przez brukselskie elity wizję wielokulturowości jako największa groźbę dla spójności narodu. Prawica nawiązywała więc do endeckiej tradycji „silnego narodu”. Co ciekawe, podobne stanowisko miała liberalna opozycja. Pod wpływem opinii publicznej i w wyniku przegranych wyborów PO uznała, że podział uchodźców

\footnotetext{
${ }^{46} \mathrm{~J}$. Kaczyński, My takiej Europy nie chcemy, Niezależna.pl, 23 maja 2019, https:// niezalezna.pl/272053-my-takiej-europy-nie-chcemy-stanowcze-slowa-prezesa-pis-na-konwencji-w-krakowie [dostęp: 2 lipca 2019].

${ }_{47}$ Z. Krasnodębski, Co dla Polski oznaczaja zmiany w Unii Europejskiej? w: „Myśląc: Polska", Konwencja Programowa Prawa i Sprawiedliwości oraz zjednoczonej prawicy, Katowice, 3-5 lipca 2015, s. 80-81.

48 Informacja Ministra Spraw Zagranicznych Jacka Czaputowicza o zadaniach polskiej polityki zagranicznej w 2018 roku, Sejm RP, 21 marca 2018, http://www.msz.gov.pl/pl/ aktualnosci/wiadomosci/minister_jacek_czaputowicz_o_priorytetach_polskiej_dyplomacji_w_2018_roku [dostęp: 27 kwietnia 2018].

49 Program PiS 2014.

50 Informacja Ministra Spraw Zagranicznych Jacka Czaputowicza...; Konrad Szymański: Strefa euro nie odjeżdża Polsce, „Rzeczpospolita”, 22 maja 2017, http://www.rp.pl/ Unia-Europejska/3052 19925-Konrad-Szymanski-Strefa-euro-nie-odjezdza-Polsce.html [dostęp: 27 kwietnia 2018].
} 
musi odbywać się na zasadach dobrowolnych i należy położyć nacisk $\mathrm{w}$ polityce unijnej na kontrolę granic zewnętrznych $\mathrm{UE}^{51}$. Jednocześnie szef PO obiecywał, że w przypadku przejęcia władzy nie będzie przyjmował nielegalnych migrantów ${ }^{52}$. W ten sposób stanowisko tej partii wyraźnie zbliżyło się do polityki rządzącego PiS.

Dla konserwatystów kluczowe znaczenie miała obrona polskiej demokracji - w tym również jej republikańskiej tradycji - przed presja ze strony UE. Politycy PiS podkreślali, że demokracja w Europie występuje przede wszystkim w państwach członkowskich, dlatego tak ważne jest respektowanie zarówno podmiotowości wszystkich krajów, jak i głosu parlamentów narodowych w decyzjach podejmowanych na szczeblu unijnym. Partia zamierzała zwiększyć udział tych parlamentów w przyszłym ustroju UE. Konserwatyści $z$ niepokojem obserwowali tendencję do zwiększania głosowania większościowego $\mathrm{w}$ instytucjach międzyrządowych, co uznawali (zgodnie $z$ tradycja republikańską Pierwszej Rzeczpospolitej) za proceder niedemokratyczny. Dlatego oponowali przeciw propozycjom wprowadzenia głosowania większościowego w UE w sprawach podatkowych oraz $\mathrm{w}$ polityce zagranicznej. Uznawali to również za zagrożenie dla polskiej suwerenności, przynajmniej od czasu przegranej batalii o reformę nicejskiego system głosowania w UE, kiedy to proponowali zmiany opierające się na tzw. metodzie pierwiastkowej lub kompromisie jagiellońskim ${ }^{53}$.

Jarosław Kaczyński bronił republikańskich wolności zarówno w Polsce, jak i w całej Europie zagrożonej przez legislację unijna, która w jego opinii umożliwiała cenzurę debaty publicznej. „Chcemy Europy wolności we wszystkich dziedzinach, także w internecie - żadnych ACTA 2! [...] Byliśmy zawsze krajem wolnym i chcemy nim pozostać, nawet jeśli zostaniemy wyspa wolności" ${ }^{54}$. Politycy PiS krytykowali też nadmierna ekspansję kompetencyjną UE wykraczająca poza to, na co zgodziły się państwa członkowskie w traktatach. W ten sposób postrzegano m.in. działania Komisji Europejskiej i Trybunału Sprawiedliwości UE (TSUE) w odniesieniu do polskiej reformy sądownictwa. Możliwość wprowadzenia gruntownych zmian sądownictwa przez parlament, a więc przez demokratyczną większość wyłoniona

51 Platforma Obywatelska, http://www.platforma.org/aktualnosc/45497/projektyplatformy-polska-europa-swiat-polskaobywatelska [dostęp: 27 kwietnia 2018].

52 Schetyna potwierdza: Nie będziemy przyjmować nielegalnych migrantów, „Newsweek”, 10 maja 2017, http://www.newsweek.pl/polska/schetyna-nie-bedziemy-przyjmowac-migrantow-po-o-uchodzcach,artykuly,409922,1.html [dostęp: 27 kwietnia 2018].

53 B. Stanley, Poland..., s. 185; M.A. Cichocki, K. Życzkowski, Institutional Design and Voting Power in the European Union, Ashgate, Burlington, VT 2010.

54 J. Kaczyński, My takiej Europy nie chcemy... 
w wyborach była - zdaniem rządu PiS - nie tylko zgodna $z$ prawem unijnym, praktyka stosowana $\mathrm{w}$ innych państwach UE, ale przede wszystkim $z$ polska konstytucją. Ponadto, w tym wypadku wyraźnie ujawniła się tradycja Pierwszej Rzeczpospolitej, która dawała pierwszeństwo „woli ludu” wyrażonej przez decyzje parlamentu ponad autonomia władzy sadowniczej.

Dla polskiej prawicy interwencja instytucji europejskich była przekroczeniem prawa traktatowego, które zastrzega reformy sądownictwa jako wyłączne uprawnienie państw członkowskich ${ }^{55}$. Krytyka polskiej reformy była postrzegana jako zbyt daleko idaca ingerencja w wewnętrzne sprawy Polski. W ten sposób została naruszona zarówno polska suwerenność, jak również polska demokracja. Według polityków konserwatywnych, instytucje unijne coraz bardziej wkraczały $\mathrm{w}$ autonomię państw członkowskich, w tym nie okazywały odpowiedniego szacunku dla narodowej tożsamości, podstawowych struktur politycznych i konstytucyjnych (art. 4 TUE), łamały traktatowa zasadę przyznania kompetencji (co oznacza, że instytucje UE nie moga przekraczać kompetencji powierzonych im w traktatach), zasadę subsydiarności i proporcjonalności (art. 5 TUE) ${ }^{56}$, a nawet unijną wartość demokracji (art. 2 TUE), gdyż zbyt dalece ingerowały w ład i decyzje demokratycznych wspólnot na poziomie narodowym. Dlatego PiS był gotów bronić autonomii polskiego państwa i ładu konstytucyjnego przed presja ze strony instytucji UE.

Ponadto, dla środowisk konserwatywnych poważnym problemem było odejście UE od wartości chrześcijańskich i prorodzinnych, a także odgórne narzucanie liberalnych norm bez poszanowania narodowej tradycji lub poglądów wyborców ${ }^{57}$. Szczególnie irytująca była promocja homoseksualizmu i prawa do aborcji m.in. na lekcjach edukacji ${ }^{58}$.

${ }_{55}$ Szef MSZ podsumowat działania resortu. Czaputowicz, Rzad podejmuje wysitki $w$ celu realizacji zobowiazań wyborczych, wPolityce.pl, 7 grudnia 2018, https://wpolityce.pl/polityka/424568-szef-msz-podsumowal-dzialania-resortu [dostęp: 27 grudnia 2018]; Eurokraci $w$ kropce. Czaputowicz: Gdy nowelizacja ustawy o SN wejdzie $w$ życie, nie będzie podstawy do utrzymywania skargi $w$ TSUE, wPolityce.pl, 10 grudnia 2018, https://wpolityce.pl/polityka/424999-eurokraci-w-kropce-niebawem-nie-bedzie-podstawy-do-skargi [dostęp: 27 grudnia 2018].

56 Subsydiarność oznacza, że władza centralna powinna być z zasady pomocnicza, ale nie ingerująca w rządzenie, które może być realizowane na niższych poziomach. Podstawowe znaczenie ma tutaj pozostawienie jak największej swobody decydowania i rządzenia na niższych poziomach demokratycznych wspólnot (np. samorządowych). $Z$ kolei proporcjonalność oznacza, że interwencja wyższego szczebla administracyjnego nie wykracza poza to, co jest absolutnie niezbędne. Por. T.G. Grosse, Unia subsydiarna, Raport dla Klubu Jagiellońskiego, Kraków 2019.

57 Program PiS 2014..., s. 12-13; Deklaracja Europejska PiS, pkt. 1 i 2.

58 B. Stanley, Poland..., s. 185. 
Jarosław Kaczyński podkreślił, że jego ugrupowanie nie chce Europy ideologicznej, która narzucałaby Polsce, w jaki sposób wychowywać dzieci, bo od tego sa rodzice. Co więcej, prowadzi to, jego zdaniem, do anihilacji narodowej kultury i do demoralizacji społeczeństwa. Jednocześnie uznał, że siły proeuropejskie atakuja Kościół katolicki w Polsce, gdyż jest największą przeszkodą dla liberalizacji i laicyzacji kraju. Należy go więc bronić za wszelką cenę przed wewnętrznymi wrogami i ich zagranicznymi protektorami. Kaczyński staną w obronie wartości chrześcijańskich, na których zbudowano Europę. Dlatego PiS proponował, aby Unia powróciła do swoich korzeni, a więc wartości podzielanych przez ojców założycieli ${ }^{59}$. W ten sposób lider PiS kontynuował tradycję nation-preserving sięgającą okresu rozbiorów.

Należy zauważyć, że całkiem odmienną ocenę reform sądownictwa w Polsce miała liberalna opozycja. Integracja europejska była w tych środowiskach szansa obrony narodu przed zewnętrznymi zagrożeniami, ochrony liberalnej demokracji w Polsce, jak również budowy w pełni liberalnego społeczeństwa wzorowanego na standardach promowanych przez UE. Wraz z upływem czasu od wejścia Polski do UE pogłębiał się spór polityczny w kraju o ocenę skutków integracji między ugrupowaniami liberalnymi (i lewicowymi) a partiami konserwatywnymi.

Możemy wymienić pięć zagrożeń wynikających $z$ integracji europejskiej postrzeganych przez polityków prawicowych. Po pierwsze, dominację wartości liberalnych w UE, których zwolennicy piętnują narodowy patriotyzm. Ponadto, normy liberalne podważają wartości ważne dla polskiej tożsamości, związane $z$ chrześcijaństwem i tradycyjnym modelem rodziny. Po drugie, dażenie elit euroentuzjastycznych do federacji w UE, co stanowi zagrożenie dla państwa, najważniejszego instrumentu realizacji interesów narodu politycznego. Nawet kontynuacja procesów integracyjnych (bez osiagania federacji) oznacza postępujący transfer kompetencji z państw członkowskich do UE, co osłabia zarówno państwa narodowe, jak i ogranicza coraz bardziej narodową suwerenność. Po trzecie, ryzykowna jest dominacja w procesach integracji Francji i Niemiec oraz interesów tych narodów nad interesami mniejszych wspólnot narodowych. Po czwarte, $z$ integracja łączy się zagrożenie dla demokracji narodowej, a więc stopniowe ograniczanie wolności i samostanowienia dla narodu politycznego. Dzieje

59 J. Kaczyński, Mamy do czynienia z coraz jawniejszym przejawem hejtu...; J. Kaczyński, My takiej Europy... 
się tak m.in. w wyniku możliwości przegłosowywania państw w procesie decyzyjnym w UE, a także rosnącej roli interpretacji sądowniczych (TSUE) $\mathrm{w}$ integracji europejskiej. Po piąte, poważnym zagrożeniem stał się niekontrolowany napływ imigrantów o obcym backgroundzie kulturowym, $z$ trudem i w niewielkim stopniu integrujacych się $z$ miejscowym społeczeństwem, co stanowi długofalowe zagrożenie dla narodu politycznego i jego kultury.

W ten sposób polska prawica coraz bardziej postrzegała integrację europejska jako zagrożenie dla narodu i państwa, zwłaszcza w tych sferach, które miały podstawowe znaczenie dla polskiej tożsamości. Dotyczy to zagrożeń w sferze kultury, religii, tradycji politycznej, suwerenności wobec zewnętrznej presji politycznej, a tym samym dla własnej państwowości, wreszcie dla republikańskiej wolności i narodowej demokracji. Dlatego w XXI wieku politycy konserwatywni podejmowali w coraz większym stopniu działania $z$ zakresu nation-preserving, mające chronić przed rozlicznymi niebezpieczeństwami. Do wcześniejszego zagrożenia ze strony Rosji coraz częściej dodawano te wynikające $z$ integracji europejskiej.

\section{PODSUMOWANIE}

W artykule tym dowodzę, że okres transformacji ustrojowej po roku 1989 był dla polskich elit, zwłaszcza prawicowych, okazja do prowadzenia polityki nation-building. Po wejściu do Unii Europejskiej podejście to $\mathrm{w}$ coraz większym stopniu zmierzało w kierunku nation-preserving.

Część naukowców wskazuje na to, że integracja europejska na wiele sposobów ogranicza państwa członkowskie ${ }^{60}$. Przede wszystkim transfer kompetencji na poziom unijny narusza suwerenność narodowa, a przynajmniej zmniejsza autonomię władz państwowych i poddaje je w dużym stopniu władzy prawa europejskiego. Państwa członkowskie uczestnicza wprawdzie w procesie decyzyjnym, ale niekiedy zostaja przegłosowane i muszą wbrew własnym preferencjom implementować decyzje instytucji unijnych. Ponadto, integracja europejska poszerza władzę instytucji unijnych, takich jak Komisja Europejska lub TSUE.

${ }^{60} \mathrm{Np.} \mathrm{H.} \mathrm{Vollaard,} \mathrm{European} \mathrm{Disintegration.} \mathrm{A} \mathrm{Search} \mathrm{for} \mathrm{Explanations,} \mathrm{Palgrave} \mathrm{Mac-}$ millan, London 2018, s. 199; S. Mangiameli, The Constitutional Sovereignty of Member States and European Constraints: The Difficult Path to Political Integration, w: The Consequences of the Crisis on European Integration and on the Member States. Essays on Federalism and Regionalism, ed. S. Mangiameli, t. 2, Springer, Cham 2017, s. 189-216; T.G. Grosse, Pokryzysowa Europa... 
$\mathrm{Na}$ ich działania pojedyncze państwo członkowskie - zwłaszcza mniejsze lub słabsze politycznie - ma niewielki wpływ, choć niejednokrotnie jest zmuszone poddać się decyzjom tych instytucji.

Naukowcy dowodza, że integracja europejska jest postrzegana przez część elit politycznych i wspólnot narodowych jako zagrożenie dla identyfikacji i kultur narodowych ${ }^{61}$. Procesy integracyjne sprzyjaja upowszechnianiu w Europie wartości liberalnych, a nawet kosmopolitycznych, jak również związanych $z$ budowaniem europejskiej federa$\mathrm{cji}^{62}$. To nie podoba się środowiskom konserwatywnym w Polsce, dla których punktem odniesienia jest inny zestaw wartości. Środowiska te sa przywiazane do państwa narodowego i narodowej demokracji.

Polityka eliminowania granic państwowych w UE - czego przykładem jest strefa Schengen i wspólna polityka uchodźcza - dodatkowo ogranicza tradycyjne kompetencje państw zwiazane $z$ ochroną własnych granic i kontrola imigracji. Dla polskiej prawicy jest to kolejny problem, gdyż integracja w tym obszarze prowadzi do napływu dużej ilości imigrantów o odmiennej kulturze, którzy nie zawsze integruja się z miejscowym społeczeństwem. Stanowi to wyzwanie dla polityków przywiazanych do tradycyjnych narodowych wartości. Kryzys migracyjny w Europie dodatkowo zajatrzył te problemy. Nic więc dziwnego, że wraz $z$ upływem czasu i kolejnymi kryzysami w UE polscy konserwatyści podchodzili do dalszej integracji sceptycznie, jak również wprowadzali działania, które w niniejszym artykule zostały zdefiniowane jako nation-preserving.

Jednocześnie polskie podejście do nation-preserving $\mathrm{w}$ dużym stopniu odwoływało się do tradycji sięgającej XIX wieku, a więc okresu rozbiorów, kiedy polskie elity starały się chronić tkankę narodową przed zewnętrznymi zagrożeniami. Współcześnie politycy prawicy świadomie bądź nieświadomie odwołują się do tych doświadczeń przynajmniej w trzech tradycyjnych nurtach. Po pierwsze w odniesieniu do ochrony narodowej suwerenności. Po drugie, w odniesieniu do ochrony narodowej kultury, tożsamości i religii. Po trzecie, w nawiązaniu do tradycji republikańskiej polskiej demokracji. W ten sposób pomimo tak wielu historycznych zmian i upływu czasu kultywowane są wzory patriotyzmu sięgające XVIII wieku.

61 L.M. McLaren, Opposition to European Integration and Fear of Loss of National Identity: Debunking a Basic Assumption Regarding Hostility to the Integration Project, „European Journal of Political Research" 2004, t. 43, s. 895-911.

62 H. Vollaard, European Disintegration..., s. 200. 